\title{
Influence of temperature on the reproductive and demographic parameters of two spider mite pests of vineyards and their natural predator
}

\author{
Menelaos C. Stavrinides • Nicholas J. Mills
}

Received: 9 June 2010/Accepted: 4 November 2010/Published online: 24 November 2010

(C) The Author(s) 2010. This article is published with open access at Springerlink.com

\begin{abstract}
We evaluated the influence of temperature on demographic parameters of two common vineyard pests, the Pacific spider mite, Tetranychus pacificus McGregor, and the Willamette spider mite, Eotetranychus willamettei (McGregor) (Acari: Tetranychidae). Additionally, we investigated the effects o f temperature on their shared predator, the western predatory mite, Galendromus occidentalis (Nesbitt) (Acari: Phytoseiidae). The intrinsic rate of increase $\left(r_{m}\right)$ was higher for $T$. pacificus than E. willamettei at 15 and $28^{\circ} \mathrm{C}$, but similar at $22^{\circ} \mathrm{C}$. G. occidentalis achieved a higher $r_{m}$ than T. pacificus from 15 to $28^{\circ} \mathrm{C}$, but the difference was significant only at $22^{\circ} \mathrm{C}$. At $34^{\circ} \mathrm{C}$, the $r_{m}$ for both $T$. pacificus and G. occidentalis was negative, while $E$. willamettei did not develop at
\end{abstract}

Handling Editor: Patrick De Clercq

M. C. Stavrinides · N. J. Mills

Department of Environmental Science,

Policy and Management, Mulford Hall, University of

California, Berkeley, CA 94720-3114, USA

M. C. Stavrinides ( $\square)$

Department of Agricultural Sciences, Biotechnology and Food Science, Cyprus University of Technology, PO Box 50329, 3603 Limassol, Cyprus

e-mail: m.stavrinides@cut.ac.cy

M. C. Stavrinides

Agricultural Research Institute (ARI),

PO Box 22016, 1516 Nicosia, Cyprus this temperature. Prey species did not affect demographic parameters of G. occidentalis. These results suggest that higher temperatures favor $T$. pacificus over the less damaging E. willamettei, and may also reduce the effectiveness of $G$. occidentalis.

Keywords Tetranychus pacificus - Eotetranychus willamettei · Galendromus occidentalis · Grapes · Life history parameters $\cdot$ Temperature

\section{Introduction}

One of the most defining characteristics of arthropod populations is their rate of population growth, usually expressed as the intrinsic rate of natural increase $\left(r_{m}\right)$ (Frazier et al. 2006). The $r_{m}$ integrates the full range of life table parameters into a single demographic term that is especially important for pest management as it allows a direct assessment of the potential for pest population growth and an initial evaluation of the potential effectiveness of natural enemies. For example, herbivorous arthropods with high $r_{m}$ values can develop population outbreaks rapidly and cause severe damage to crops (Sabelis 1985). On the other hand, predators with $r_{m}$ values equal to or higher than those of their prey can reach favorable predator-prey ratios and therefore provide effective control of pest populations (Janssen and Sabelis 1992; Nomikou et al. 2001). 
The $r_{m}$ of arthropod populations depends on species-specific life table parameters, such as agespecific survivorship, time to first reproduction, daily fecundity and sex ratio (Carey 1993). Positive values of $r_{m}$ signify a growing population, whereas a negative $r_{m}$ value describes a population in decline. Because arthropods are poikilothermic, temperature has a substantial influence on $r_{m}$ values through its effects on development time, fecundity and other life table parameters of a species (Roy et al. 2003a; Gotoh et al. 2004). For example, the $r_{m}$ value of an insect or mite can increase substantially as a result of a reduction in time to first reproduction at higher temperatures (Danks 2006). Small increases in $r_{m}$ can result in considerable differences in population densities because of the exponential nature of population growth. Consequently, knowledge of the effects of temperature on the $r_{m}$ of herbivore pests and their predators allows a detailed assessment of the likelihood of pest outbreaks.

Spider mites (Acari: Tetranychidae) are a welldocumented example of plant-feeding pests with high $r_{m}$ values and are notorious for their ability to develop damaging outbreaks on a wide range of cultivated crops (Sabelis 1985). The Pacific spider mite, Tetranychus pacificus McGregor, and the Willamette spider mite, Eotetranychus willamettei (McGregor), are the two most important spider mite pests in California vineyards (Welter et al. 1989; Bentley et al. 2006). T. pacificus causes significant damage during the main part of the growing season in warm inland and coastal vineyards, while E. willamettei damages grape plants during the early part of the season in inland vineyards and throughout the season in cooler, coastal vineyards (Bentley et al. 2006). Thus, climatic factors such as temperature may influence the distribution and abundance of the two mite species. Although the influence of temperature on $r_{m}$ for T. pacificus has been studied on other host plants (Takafuji and Chant 1976; Carey and Bradley 1982; Youngman et al. 1988), there is no information on demographic parameters for grapes and no studies have ever addressed demographic parameters for E. willamettei.

The western predatory mite, Galendromus occidentalis (Nesbitt) (Acari: Phytoseiidae), is an important predator of $T$. pacificus and E. willamettei in vineyards (Hoy and Smilanick 1981; Hanna and Wilson 1991; Flaherty et al. 1992; Bentley et al.
2006). In the absence of disruptive pesticide applications (Flaherty and Huffaker 1970; Stavrinides and Mills 2009) the predatory mite seems to provide good control earlier in the season, but fails to prevent outbreaks of $T$. pacificus during the hot summer months suggesting that higher temperatures may limit its effectiveness. While the influence of temperature on $r_{m}$ for $G$. occidentalis has been studied before (Croft and McMurtry 1972; Tanigoshi et al. 1975; Badii and McMurtry 1984; Bruce-Oliver and Hoy 1990), no studies have addressed demographic parameters of the predatory mite on $T$. pacificus feeding on grape plants at the full range of temperatures representative of California vineyards. In addition, no studies have estimated demographic parameters for G. occidentalis feeding on E. willamettei, and yet prey species can be an important factor determining the population growth and effectiveness of mite predators (e.g. Escudero and Ferragut 2005; de Vasconcelos et al. 2008).

Here, we investigate adult life table parameters of T. pacificus, E. willamettei and G. occidentalis feeding on $T$. pacificus at four temperatures ranging from 15 to $34^{\circ} \mathrm{C}$. In addition, we compare adult life table parameters of $G$. occidentalis feeding on either T. pacificus or E. willamettei at $28^{\circ} \mathrm{C}$. These data are combined with previous estimates of the influence of temperature on the development and survivorship of immature stages (Stavrinides et al. 2010a) to generate life table estimates of the demographic characteristics of each species in relation to temperature. Our aim is to develop a better understanding of the influence of temperature on distribution, population outbreaks and biological control of the two spider mites.

\section{Materials and methods}

Mite sources

Both T. pacificus and E. willamettei were collected from two vineyards of variety Zinfandel in the summer of 2005 in Lodi, California, USA (T. pacificus: $38^{\circ} 11^{\prime} 9.26^{\prime \prime} \mathrm{N}, 121^{\circ} 17^{\prime} 42.87^{\prime \prime} \mathrm{W} ;$ E. willamettei: $38^{\circ}$ $\left.7^{\prime} 10.06^{\prime \prime} \mathrm{N}, 121^{\circ} 11^{\prime} 46.08^{\prime \prime} \mathrm{W}\right)$. The spider mites were cultured on Chardonnay grape plants at $28.3 \pm 1.5^{\circ} \mathrm{C}$, $26.6 \pm 10 \% \mathrm{RH}$ for $E$. willamettei and $29.6 \pm 1.5^{\circ} \mathrm{C}$, $25.0 \pm 5 \% \mathrm{RH}$ for $T$. pacificus with a 18:6 h L:D photoperiod. We obtained $G$. occidentalis from 
Sterling Insectaries (McFarland, CA, USA) raised on two-spotted spider mites (Tetranychus urticae Koch). Predatory mites were fed with T. pacificus at $28^{\circ} \mathrm{C}$ for at least $24 \mathrm{~h}$ before collecting eggs for experiments.

\section{Experimental procedures}

Adult life table parameters were estimated at 15, 22, 28 and $34^{\circ} \mathrm{C}\left( \pm 1^{\circ} \mathrm{C}\right.$-range of daily average $)$ and a 16:8 h L:D photoperiod for T. pacificus, E. willamettei and G. occidentalis feeding on T. pacificus. In addition, we compared adult life table parameters for G. occidentalis feeding on T. pacificus or E. willamettei at $28^{\circ} \mathrm{C}$.

Experiments were carried out on $20 \mathrm{~mm}$ grape leaf disks of clone Chardonnay 4 grafted on rootstock SO4 (Duarte Nurseries, Inc., Hughson, CA, USA). Each leaf disk was placed with its lower surface facing up on top of seven $25 \mathrm{~mm}$ diameter filter papers moistened with distilled water in a small $25 \times 13 \mathrm{~mm}$ (diameter $\times$ height) Petri dish. The lid of the Petri dish had a $5.5 \mathrm{~mm}$ hole covered with a mesh screen $(50 \times 50 \mu \mathrm{m}$ openings, Small Parts, Inc. Hollywood, FL, USA).

We obtained synchronous cohorts for experiments by transferring 20 female mites on a grape leaf disk and allowing them to oviposit for $12 \mathrm{~h}$ at $28^{\circ} \mathrm{C}$. For experiments at $34^{\circ} \mathrm{C}$, mites were allowed to oviposit for $8 \mathrm{~h}$. Leaf disks used for G. occidentalis egg laying were infested with all stages of T. pacificus. Hatching mites were kept individually on leaf disks and observations on immature development were made every $48 \mathrm{~h}$ at $15^{\circ} \mathrm{C}$, every $24 \mathrm{~h}$ at $22^{\circ} \mathrm{C}$, every $12 \mathrm{~h}$ at $28^{\circ} \mathrm{C}$ and every $8 \mathrm{~h}$ at $34^{\circ} \mathrm{C}$. T. pacificus and E. willamettei were provided with a male for mating when they reached the third quiescent stage, just before adult emergence, while $G$. occidentalis females were provided with a male on adult emergence. Females were kept with a male throughout their life. Data on immature development of the three mites are presented in Stavrinides et al. (2010a).

Observations on the preoviposition period, fecundity and adult longevity were made every $48 \mathrm{~h}$ for $15^{\circ} \mathrm{C}$ and every $24 \mathrm{~h}$ for all other temperatures. We replaced leaf disks for $T$. pacificus and E. willamettei as needed to ensure a fresh green color. For $G$. occidentalis we either supplied all stages of spider mites or replaced leaf disks as needed to ensure an abundance of prey.
Eggs laid by experimental females at 22, 28 and $34^{\circ} \mathrm{C}$ were raised to adult at the same temperature as their parents to determine progeny sex ratio $(\%$ females). To determine whether sex ratio varied through the reproductive life of a female, at $28^{\circ} \mathrm{C}$ we compared estimates for progeny obtained from the first $50 \%$ and last $50 \%$ of the reproductive period. A $G$-test (with Yates correction for continuity) suggested that sex ratio estimates from the two halves of the reproductive life were not significantly different for any of the mite species $(G=1.53$, $d f=1, P=0.22$ for $T$. pacificus, $G=0.05, d f=1$, $P=0.82$ for $E$. willamettei and $G=0.006, d f=1$, $P=0.94$ for $G$. occidentalis on T. pacificus). Therefore, for the study of G. occidentalis on E. willamettei at $28^{\circ} \mathrm{C}$ and all experiments at $22^{\circ} \mathrm{C}$ we estimated sex ratio based on eggs collected over a period estimated to represent approximately $50 \%$ of the lifetime fecundity of each female. We used sex ratio estimates at $22^{\circ} \mathrm{C}$ for life table estimation at $15^{\circ} \mathrm{C}$, as it was not practical to carry out sex ratio observations at this temperature. Similarly, as no G. occidentalis eggs developed to adult at $34^{\circ} \mathrm{C}$, we used the sex ratio at $28^{\circ} \mathrm{C}$ for life table estimation. Finally, as $T$. pacificus females laid only a few eggs at $34^{\circ} \mathrm{C}$ we used progeny produced throughout adult life to estimate their sex ratios.

\section{Statistical analyses}

We compared lifetime fecundity and adult longevity between species at each temperature with oneway ANOVA using the function aov in the stats package of $\mathrm{R}$ v.2.7.1 ( $\mathrm{R}$ core development team 2008), followed by the Tukey honestly significant difference (Tukey HSD) multiple comparison test. Residual plots for data on fecundity and longevity revealed no major departures from the assumptions of normality and variance homogeneity. Because preoviposition period followed a non-normal distribution, it was analyzed using the non-parametric Kruskal-Wallis test in R v. 2.7.1, followed by nonparametric multiple comparisons using the function kruskalmc in the $\mathrm{R}$ package pgirmess (Giraudoux 2008).

We described the daily fecundity of mites $\left(m_{x}\right)$ using a modified version of the Bieri et al. (1983) model: 
$m_{x}=a(x-c) / b^{x-c}$

where $x$ is the age of the females since adult emergence in days, $a$ and $b$ are fitted constants and $c$ represents the preoviposition period. The model was fitted to the data in SAS/STAT ${ }^{\circledR}$ software, version 9.1 for Windows using the procedure NLIN with the Gauss-Newton algorithm (SAS Institute Inc. 2004). Parameter $c$ for G. occidentalis at $15^{\circ} \mathrm{C}$ was constrained to be equal to or greater than zero because the unconstrained model estimate was otherwise negative.

We constructed fertility life tables (Birch 1948) for the three mite species and estimated demographic parameters in SAS/STAT 9.1 using the program developed by Maia et al. (2000). The demographic parameters estimated were net reproductive rate $(R o)$, intrinsic rate of increase $\left(r_{m}\right)$, mean generation time $(T)$, and doubling time $(D t)$. The program employs an iterative approach to estimate the population growth parameters, and a jackknife approach to generate variance estimates for each parameter and to construct $t$-tests for pairwise comparisons. We present true (non-jackknife) estimates of $r_{m}$ and $D t$ at $34^{\circ} \mathrm{C}$ as jackknife estimates were substantially different from the true estimates suggesting that the jackknife approach was not appropriate for these negative values (Maia et al. 2000). At all other temperatures jackknife estimates were within $1 \%$ of true estimates. Where appropriate, $P$ values were corrected using the false discovery rate correction at the level of 0.05 (Benjamini and Hochberg 1995) to account for multiple tests.

\section{Results}

Comparisons of reproductive parameters and longevity for T. pacificus, E. willamettei and G. occidentalis feeding on T. pacificus

The preoviposition period at $15^{\circ} \mathrm{C}$ was longer for G. occidentalis, intermediate for E. willamettei and shorter for T. pacificus (Kruskal-Wallis $\chi^{2}=11.64$, $d f=2, P=0.003$, Table 1 ). At $22^{\circ} \mathrm{C}$ the preoviposition period was similar for all three mites (KruskalWallis $\chi^{2}=0.06, d f=2, P=0.97$, Table 1). At $28^{\circ} \mathrm{C}$ there was significant variation in the preoviposition period of the three mites (Kruskal-Wallis $\chi^{2}=10.36, d f=2, P=0.006$, Table 1). However, the non-parametric multiple comparisons procedure failed to identify pairwise significant differences. At $34^{\circ} \mathrm{C}, T$. pacificus exhibited a significantly shorter preoviposition period than G. occidentalis (KruskalWallis $\chi^{2}=20.38, d f=1, \quad P<0.001$, Table 1 ). E. willamettei did not develop at $34^{\circ} \mathrm{C}$ (Stavrinides et al. 2010a).

Lifetime fecundity for $T$. pacificus at $15^{\circ} \mathrm{C}$ was significantly higher than that for G. occidentalis, whereas that for $E$. willamettei was intermediate $\left(F_{2,62}=3.80, P=0.03\right.$, Fig. 1$)$. At $22^{\circ} \mathrm{C}$, the lifetime fecundity for $T$. pacificus was higher than that for $E$. willamettei with that for $G$. occidentalis intermediate $\left(F_{2,67}=6.09, P=0.004\right.$, Fig. 1). At $28^{\circ} \mathrm{C}$, the lifetime fecundity for $T$. pacificus was significantly higher than that for either $E$. willamettei or G. occidentalis $\left(F_{2,54}=12.38, P<0.001\right.$, Fig. 1$)$, and at $34^{\circ} \mathrm{C} T$. pacificus again laid significantly more

Table 1 Preoviposition period and adult female longevity (mean ${ }^{\mathrm{a}} \pm \mathrm{SE}$ ) at different temperatures for T. pacificus, E. willamettei and G. occidentalis feeding on T. pacificus

\begin{tabular}{|c|c|c|c|c|}
\hline Temperature & $15^{\circ} \mathrm{C}$ & $22^{\circ} \mathrm{C}$ & $28^{\circ} \mathrm{C}$ & $34^{\circ} \mathrm{C}$ \\
\hline \multicolumn{5}{|c|}{ Preoviposition period (days) } \\
\hline T. pacificus & $3.33 \pm 0.37 \mathrm{~b}[15]$ & $2.13 \pm 0.22 \mathrm{a}[15]$ & $0.70 \pm 0.12$ a $[23]$ & $0.18 \pm 0.11 \mathrm{~b}[22]$ \\
\hline E. willamettei & $3.91 \pm 0.46 \mathrm{ab}[22]$ & $2.38 \pm 0.42$ a $[15]$ & $1.11 \pm 0.07$ a $[19]$ & - \\
\hline G. occidentalis & $5.86 \pm 0.61$ a $[28]$ & $2.04 \pm 0.04$ a $[28]$ & $1.07 \pm 0.07 \mathrm{a}[14]$ & $1.92 \pm 0.38$ a $[13]$ \\
\hline \multicolumn{5}{|c|}{ Adult female longevity (days) } \\
\hline T. pacificus & $46.59 \pm 5.08$ a [17] & $45.33 \pm 3.85$ a $[15]$ & $12.04 \pm 1.20$ a $[23]$ & $5.28 \pm 0.28$ a [29] \\
\hline E. willamettei & $33.57 \pm 3.15$ b [23] & $19.96 \pm 2.19 \mathrm{~b}[16]$ & $7.85 \pm 0.71 \mathrm{~b}[20]$ & - \\
\hline G. occidentalis & $28.57 \pm 2.59$ b [28] & $18.43 \pm 1.92$ b $[28]$ & $14.14 \pm 1.79$ a $[14]$ & $5.24 \pm 0.64$ a $[21]$ \\
\hline
\end{tabular}

\footnotetext{
${ }^{a}$ Sample size in square brackets. Means followed by different letters within each life history parameter and temperature are significantly different $(P<0.05$, non-parametric multiple comparison test for preoviposition period, and a Tukey honestly significant difference test for adult female longevity)
} 
Fig. 1 Lifetime fecundity (mean $\pm \mathrm{SE}$ ) for T. pacificus, E. willamettei and $G$. occidentalis feeding on $T$. pacificus at different temperatures. Sample sizes as for adult female longevity in Table 1. For each temperature means with different letters are significantly different $(P<0.05$, Tukey honestly significant difference test)
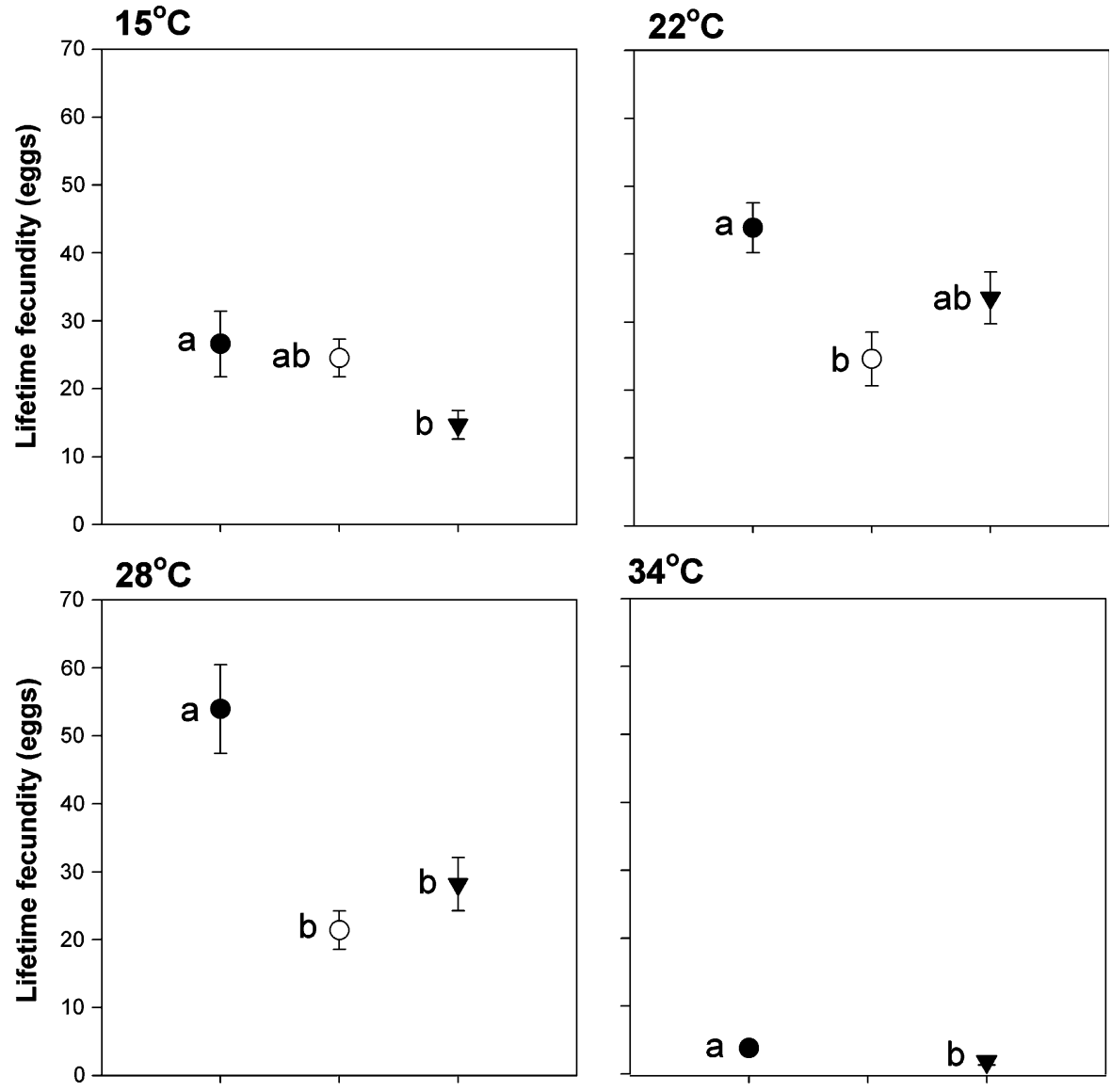

T. pac. E. will. G. occid.



T. pac. E. will. G. occid. eggs than $G$. occidentalis $\left(F_{1,48}=4.79, P=0.03\right.$, Fig. 1).

Daily fecundity $\left(m_{x}\right)$ followed a similar pattern for $T$. pacificus and $E$. willamettei with an initial increase to a peak followed by a period of decrease (Fig. 2). The decrease in daily fecundity for G. occidentalis was less steep than for the two spider mites (Fig. 2) giving the curve a flatter shape. At most temperatures daily fecundity peaked earlier for $T$. pacificus than for E. willamettei while daily fecundity for G. occidentalis peaked later than that for either spider mite. There was considerable variation around the fitted models as shown by the $R^{2}$ values (Fig. 2), and the preoviposition period estimated by parameter $c$ of the Bieri model differed from the actual mean preoviposition periods estimated from direct observation for most species/temperature combinations (Table 1).

The sex ratio (percentage females) at $22^{\circ} \mathrm{C}$ was $66.94,87.01$ and $69.90 \%$ for $T$. pacificus,
E. willamettei and G. occidentalis, respectively. At $28^{\circ} \mathrm{C}$, the sex ratio was $72.39,66.44$ and $66.41 \%$ for $T$. pacificus, E. willamettei and G. occidentalis, respectively. At $34^{\circ} \mathrm{C}$ the sex ratio was $63.79 \%$ for T. pacificus. No sex ratio estimate was obtained for G. occidentalis at $34^{\circ} \mathrm{C}$ as the great majority of eggs laid by experimental females did not hatch and none of the immatures survived to the adult stage.

Longevity for adult females was significantly higher for $T$. pacificus than for $G$. occidentalis or E. willamettei at 15 and $22^{\circ} \mathrm{C}\left(F_{2,65}=6.63, P=\right.$ 0.002 and $F_{2,67}=34.40, P<0.001$, respectively, Table 1). At $28^{\circ} \mathrm{C}$, G. occidentalis and T. pacificus lived significantly longer than $E$. willamettei $\left(F_{2,54}=\right.$ $6.48, P=0.003$, Table 1$)$, whereas longevity for $G$. occidentalis and $T$. pacificus was similar at $34^{\circ} \mathrm{C}$ $\left(F_{1,48}=0.004, \quad P=0.95\right.$, Table 1). Age-specific survivorship $\left(l_{x}\right)$ for adult females decreased with temperature for all species (Fig. 2). At 15 and $22^{\circ} \mathrm{C}$ 


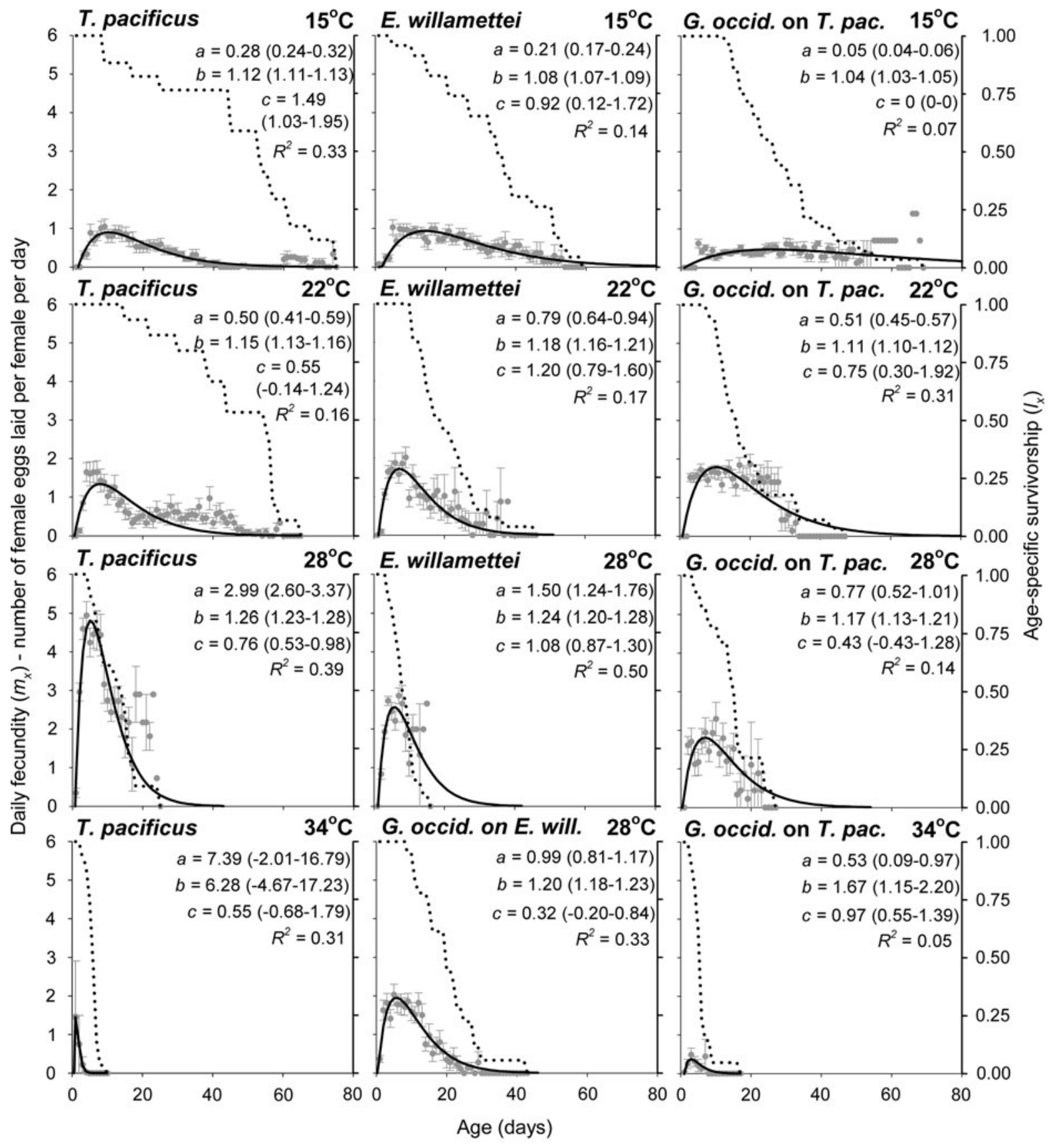

- Actual data for daily fecundity $\left(m_{X}\right)$

Fitted curve for $m_{x}$

Age-specific survivorship $\left(I_{x}\right)$

Fig. 2 Daily fecundity ( $m_{x}$, grey circles) and age-specific survivorship ( $l_{x}$, dotted lines) for adult females of $T$. pacificus, E. willamettei and G. occidentalis feeding on T. pacificus or E. willamettei at different temperatures (mean $\pm \mathrm{SE}$ ). Daily fecundity for each female was multiplied by the progeny sex ratio to obtain the number of female eggs laid per day. Fitted curves for $m_{x}$ (solid lines) and associated parameters (mean, 95\% CI) from a modified version of the Bieri et al. (1983) model. For all models $P<0.001$ ( $F$-test for model fit). Initial cohort sizes as for adult female longevity in Table 1 
Table 2 Jackknife estimates ${ }^{\mathrm{a}}$ and associated standard errors of demographic parameters for T. pacificus, E. willamettei and G. occidentalis feeding on T. pacificus. Sample sizes are the same as for adult female longevity in Table 1

\begin{tabular}{|c|c|c|c|c|}
\hline Temperature & $15^{\circ} \mathrm{C}$ & $22^{\circ} \mathrm{C}$ & $28^{\circ} \mathrm{C}$ & $34^{\circ} \mathrm{C}$ \\
\hline \multicolumn{5}{|c|}{ Net reproductive rate $\left(R_{o}\right)$} \\
\hline T. pacificus & $13.61 \pm 2.47 \mathrm{a}$ & $26.21 \pm 2.18 \mathrm{a}$ & $35.94 \pm 4.35 \mathrm{a}$ & $0.73 \pm 0.13^{\mathrm{b}} \mathrm{a}$ \\
\hline E. willamettei & $6.57 \pm 0.75 b$ & $15.13 \pm 1.86 \mathrm{~b}$ & $8.89 \pm 1.18 \mathrm{c}$ & - \\
\hline G. occidentalis & $8.23 \pm 1.20 \mathrm{ab}$ & $22.13 \pm 2.51 \mathrm{ab}$ & $18.05 \pm 2.52 \mathrm{~b}$ & $0.87 \pm 0.23^{\mathrm{b}} \mathrm{a}$ \\
\hline \multicolumn{5}{|c|}{ Intrinsic rate of natural increase $\left(r_{m}\right)$} \\
\hline T. pacificus & $0.061 \pm 0.004 \mathrm{a}$ & $0.119 \pm 0.006 \mathrm{~b}$ & $0.272 \pm 0.006 \mathrm{a}$ & $-0.031^{\mathrm{c}}$ \\
\hline E. willamettei & $0.043 \pm 0.002 \mathrm{~b}$ & $0.130 \pm 0.004 \mathrm{~b}$ & $0.161 \pm 0.007 \mathrm{~b}$ & - \\
\hline G. occidentalis & $0.068 \pm 0.002 \mathrm{a}$ & $0.206 \pm 0.005 \mathrm{a}$ & $0.290 \pm 0.014 \mathrm{a}$ & $-0.014^{\mathrm{c}}$ \\
\hline \multicolumn{5}{|c|}{ Mean generation time $(T)$} \\
\hline T. pacificus & $43.35 \pm 0.91 \mathrm{a}$ & $27.44 \pm 1.36 \mathrm{a}$ & $13.17 \pm 0.43 \mathrm{a}$ & $10.00 \pm 0.09 \mathrm{a}$ \\
\hline E. willamettei & $43.56 \pm 0.91 \mathrm{a}$ & $20.93 \pm 0.71 \mathrm{~b}$ & $13.66 \pm 0.34 \mathrm{a}$ & - \\
\hline G. occidentalis & $31.33 \pm 2.17 \mathrm{~b}$ & $15.09 \pm 0.70 \mathrm{c}$ & $10.01 \pm 0.37 \mathrm{~b}$ & $9.94 \pm 0.52 \mathrm{a}$ \\
\hline \multicolumn{5}{|c|}{ Population doubling time $\left(D_{t}\right)$} \\
\hline T. pacificus & $11.39 \pm 0.71 \mathrm{~b}$ & $5.82 \pm 0.29 \mathrm{a}$ & $2.54 \pm 0.06 \mathrm{~b}$ & $-22.11^{\mathrm{c}}$ \\
\hline E. willamettei & $15.94 \pm 0.82 \mathrm{a}$ & $5.32 \pm 0.17 \mathrm{a}$ & $4.30 \pm 0.20 \mathrm{a}$ & - \\
\hline G. occidentalis & $10.25 \pm 0.30 \mathrm{~b}$ & $3.37 \pm 0.09 \mathrm{~b}$ & $2.39 \pm 0.11 \mathrm{~b}$ & $-50.92^{\mathrm{c}}$ \\
\hline
\end{tabular}

${ }^{a}$ Means followed by different letters within each demographic parameter and temperature are significantly different $(P<0.05)$

b $95 \%$ confidence intervals included 1

c True estimates are presented as jackknife estimates were not appropriate for these negative values

the decrease in $l_{x}$ for $T$. pacificus was less steep than for E. willamettei and G. occidentalis, while $l_{x}$ differences were less marked at higher temperatures.

Comparisons of demographic parameters for T. pacificus, E. willamettei and G. occidentalis feeding on $T$. pacificus

The net reproductive rate $\left(R_{o}\right)$ for $T$. pacificus was significantly higher than that for $E$. willamettei between 15 and $28^{\circ} \mathrm{C}$ with that for G. occidentalis intermediate (Table 2). However, the differences between the $R_{o}$ for $G$. occidentalis and that for the two spider mites were significant only at $28^{\circ} \mathrm{C}$. At $34^{\circ} \mathrm{C} R_{o}$ for $T$. pacificus and G. occidentalis were very similar and less than one (Table 2). The $r_{m}$ for T. pacificus was significantly higher than that for E. willamettei at 15 and $28^{\circ} \mathrm{C}$, but not at $22^{\circ} \mathrm{C}$. While $r_{m}$ for $G$. occidentalis was significantly higher than that for E. willamettei at all temperatures, it was significantly greater than that for $T$. pacificus only at $22^{\circ} \mathrm{C}$. At $34^{\circ} \mathrm{C} r_{m}$ for $G$. occidentalis and T. pacificus were negative (Table 2). Differences in population doubling time $\left(D_{t}\right)$ followed a similar pattern as those for $r_{m}$ (Table 2). Mean generation time ( $T$ ) for T. pacificus was similar to that for E. willamettei at 15 and $28^{\circ} \mathrm{C}$, but significantly higher at $22^{\circ} \mathrm{C}$. Generation time for $G$. occidentalis was significantly shorter than that for either spider mite at temperatures up to $28^{\circ} \mathrm{C}$ (Table 2). At $34^{\circ} \mathrm{C}, T$ for $G$. occidentalis and $T$. pacificus was similar.

Effect of mite prey on G. occidentalis longevity and reproductive/demographic parameters at $28^{\circ} \mathrm{C}$

The preoviposition period for G. occidentalis feeding on E. willamettei was significantly shorter (KruskalWallis $\chi^{2}=5.03, d f=1, P=0.03$ ) than that for G. occidentalis feeding on T. pacificus (Table 3). G. occidentalis lifetime fecundity when feeding on E. willamettei was significantly higher $\left(F_{1,30}=4.63\right.$, $P=0.04)$ than when feeding on $T$. pacificus (Table 3 ). The daily fecundity for G. occidentalis feeding on E. willamettei peaked earlier than that for G. occidentalis feeding on T. pacificus (Fig. 2). Sex ratio for G. occidentalis feeding on $T$. pacificus was higher than when $E$. willamette $i$ was provided as prey 
Table 3 Longevity and reproductive/demographic parameters $\left(\right.$ mean $\left.^{\mathrm{a}} \pm \mathrm{SE}\right)$ for $G$. occidentalis feeding on $T$. pacificus or E. willamettei at $28^{\circ} \mathrm{C}$

\footnotetext{
a Means followed by different letters within each parameter are significantly different $(P<0.05$, see results for type of test)
}

\begin{tabular}{lll}
\hline Parameter & Prey \\
\cline { 2 - 3 } & T. pacificus $(n=14)$ & E. willamettei $(n=18)$ \\
\hline Preoviposition period (days) & $1.07 \pm 0.07 \mathrm{a}$ & $0.72 \pm 0.25 \mathrm{~b}$ \\
Adult female longevity (days) & $14.14 \pm 1.79 \mathrm{a}$ & $19.67 \pm 1.98 \mathrm{a}$ \\
Lifetime fecundity & $28.14 \pm 3.93 \mathrm{~b}$ & $41.78 \pm 4.67 \mathrm{a}$ \\
Sex ratio & $66.41 \% \mathrm{a}$ & $55.29 \% \mathrm{~b}$ \\
Net reproductive rate $\left(R_{o}\right)$ & $18.05 \pm 2.52 \mathrm{a}$ & $22.09 \pm 2.47 \mathrm{a}$ \\
Intrinsic rate of natural increase $\left(r_{m}\right)$ & $0.290 \pm 0.014 \mathrm{a}$ & $0.307 \pm 0.012 \mathrm{a}$ \\
Mean generation time $(T)$ & $10.01 \pm 0.37 \mathrm{a}$ & $10.09 \pm 0.36 \mathrm{a}$ \\
Population doubling time $\left(D_{t}\right)$ & $2.39 \pm 0.11 \mathrm{a}$ & $2.25 \pm 0.09 \mathrm{a}$ \\
\hline
\end{tabular}

$(G=6.00, d f=1, P=0.01$, Table 3$)$. Longevity for female $G$. occidentalis feeding on E. willamettei was not significantly different $\left(F_{1,30}=4.05\right.$, $P=0.05)$ than that for $G$. occidentalis feeding on T. pacificus (Table 3 ). The demographic parameters for G. occidentalis feeding on E. willamettei at $28^{\circ} \mathrm{C}$ were not significantly different $(P>0.05)$ than when feeding on T. pacificus (Table 3).

\section{Discussion}

T. pacificus exhibited a significantly higher $r_{m}$ than E. willamettei at both 15 and $28^{\circ} \mathrm{C}$, while at $22^{\circ} \mathrm{C}$ the $r_{m}$ for the two mites was similar. The differences in $r_{m}$ between the two mites resulted from contrasting patterns of survivorship $\left(l_{x}\right)$ and, or daily fecundity $\left(m_{x}\right)$ that are reflected in the parameters $R_{o}$ and $T$. For example, the higher $r_{m}$ for $T$. pacificus than for E. willamettei at 15 and $28^{\circ} \mathrm{C}$ was driven by a higher $R_{o}$ (Table 2) that resulted from its generally higher fecundity and immature and adult survival (Figs. 1, 2, Stavrinides et al. 2010a). Although survivorship and $R_{o}$ were also higher for $T$. pacificus than E. willamettei at $22^{\circ} \mathrm{C}$ (Table 2; Fig. 2; Stavrinides et al. 2010a), the shorter $T$ for the latter species at this temperature caused partly by a greater emphasis on early reproduction (Fig. 2) resulted in a similar $r_{m}$ for the two mites.

Previous studies have also reported a higher fecundity for Tetranychus than Eotetranychus species (Bonfour and Tanigoshi 2001; Grissa-Lebdi et al. 2002) and the sex ratios estimated here for the two species are within the range of those reported in the literature (Carey and Bradley 1982; Bonato et al. 1990; Bonfour and Tanigoshi 2001; Grissa-Lebdi et al. 2002; Roy et al. 2003b). However, the use of sex ratio estimates at $22^{\circ} \mathrm{C}$ to estimate demographic parameters at $15^{\circ} \mathrm{C}$ may have led to a slight underestimation of $r_{m}$ at this lower temperature because of the concave shape of the curve describing the relationship between temperature and sex ratio (Roy et al. 2003b).

The $r_{m}$ values estimated for $E$. willamettei in this study are comparable to the range of 0.101 at $24^{\circ} \mathrm{C}$ to 0.170 at $25^{\circ} \mathrm{C}$ reported for other Eotetranychus species (Castagnoli et al. 1989; Bonato et al. 1990; Bonfour and Tanigoshi 2001; Grissa-Lebdi et al. 2002). Similarly, the higher $r_{m}$ values estimated for T. pacificus fall within the range of 0.150-0.293 at $25^{\circ} \mathrm{C}$ reported for other Tetranychus species (Takafuji and Chant 1976; Carey and Bradley 1982; Bonfour and Tanigoshi 2001; Grissa-Lebdi et al. 2002; Kasap 2004; Roy et al. 2003a). The higher $r_{m}$ values for Tetranychus than Eotetranychus species may be a result of intense selection for high population growth because of the need for continuous re-colonization of ephemeral herbaceous host plants. Spider mites in the genus Tetranychus have a wider host range that includes herbaceous and woody plants, whereas the genus Eotetranychus is usually confined to woody host plants (Bolland et al. 1998). Another possibility is that woody plants are better defended and less nutritious than herbaceous plants (Sabelis 1985), although our results and other studies show that Tetranychus do better than Eotetranychus even on woody plants (Bonfour and Tanigoshi 2001; Grissa-Lebdi et al. 2002).

Based on the effects of temperature on the $r_{m}$ of E. willamettei and T. pacificus, we would expect both spider mites to be found in vineyards early in the season with $T$. pacificus becoming more prevalent as 
temperatures increase and its $r_{m}$ becomes significantly higher than that for E. willamettei (Table 2). For example, as $r_{m}$ was almost twice as high for T. pacificus than for E. willamettei at $28^{\circ} \mathrm{C}$ this would allow T. pacificus to outgrow a population of E. willamettei of the same size by a factor of 20 over a four-week period. During the early season (May to June), however, E. willamettei develops higher populations than T. pacificus in many inland vineyards before $T$. pacificus becomes dominant as temperatures rise (Bentley et al. 2006). In addition, in many areas with a cool climate, such as coastal vineyards, E. willamettei remains more abundant than $T$. pacificus throughout the season. The higher abundance of E. willamettei than $T$. pacificus in vineyards at lower temperatures, although its $r_{m}$ is equal to or lower than that for T. pacificus, may result from its ability to induce defenses in grape plants against T. pacificus (e.g. Hougen-Eitzman and Karban 1995; Karban et al. 1997). Other factors such as differences in the grape varieties planted in each area may also influence the performance and abundance of the two spider mites (English-Loeb et al. 1998). Another possible explanation is that E. willamettei completes its overwintering earlier than T. pacificus, although anecdotal evidence suggests that both spider mites become active at around the same time (Karban et al. 1997). Further studies are required to understand how the interplay between biotic and abiotic factors influences the outcome of competition between the two spider mites.

An important characteristic of effective natural enemies is their ability to attain an equal or higher $r_{m}$ than their prey (Janssen and Sabelis 1992; Nomikou et al. 2001). Although G. occidentalis laid significantly fewer eggs than $T$. pacificus at all temperatures, its shorter generation time driven by its faster immature development (Stavrinides et al. 2010a) resulted in a higher $r_{m}$ than for T. pacificus up to $28^{\circ} \mathrm{C}$, although this difference was significant only at $22^{\circ} \mathrm{C}$. The smaller difference in $r_{m}$ between predator and prey at 28 than $22^{\circ} \mathrm{C}$ may allow $T$. pacificus populations to escape control at higher temperatures as suggested by field observations (Bentley et al. 2006), especially if the densities of G. occidentalis are low as T. pacificus populations begin to increase. At $34^{\circ} \mathrm{C}$, the $r_{m}$ for both $G$. occidentalis and T. pacificus was negative, but unlike T. pacificus, none of the G. occidentalis eggs laid by experimental females developed to adults. In addition, in another study we found that the upper development threshold for T. pacificus was $40^{\circ} \mathrm{C}, 3^{\circ} \mathrm{C}$ higher than that for G. occidentalis (Stavrinides et al. 2010a). Although these findings suggest an increased tolerance of high temperatures by $T$. pacificus than G. occidentalis, further life history studies at temperatures higher than $30^{\circ} \mathrm{C}$ are needed to clarify the response of the two mites to temperature extremes.

The preoviposition period was significantly shorter and lifetime fecundity significantly higher for G. occidentalis feeding on E. willamettei than on T. pacificus at $28^{\circ} \mathrm{C}$, suggesting that the former is better as prey for the predatory mite. However, the sex ratio for $G$. occidentalis was significantly higher when feeding on T. pacificus than on E. willamettei. It is not clear what caused the lower sex ratio when fed E. willamettei, especially since other predatory mites exhibit higher sex ratios on more favorable than less favorable prey (Escudero and Ferragut 2005). The combined life history parameters for G. occidentalis feeding on either spider mite resulted in very similar demographic rates. Thus, it seems that any nutritional differences between the two spider mites are not high enough to influence the performance of G. occidentalis. The higher $r_{m}$ for G. occidentalis than for E. willamettei suggests that the predatory mite can effectively control the latter over the temperature range suitable for development of either species. However, the more dispersed distribution of E. willamettei than $T$. pacificus on grape leaves (Hanna and Wilson 1991) may influence the overall effectiveness of the predatory mite in vineyards.

The $r_{m}$ values estimated here for G. occidentalis feeding on T. pacificus and E. willamettei are on the high end of the range from 0.150 at $21^{\circ} \mathrm{C}$ to 0.260 at $25^{\circ} \mathrm{C}$ reported in previous studies using $T$. pacificus as prey (Tanigoshi et al. 1975; Badii and McMurtry 1984; Bruce-Oliver and Hoy 1990). This may in part be due to the use of a different strain of the predator, although Croft and McMurtry (1972) found no significant differences in development rate and fecundity between four different strains of G. occidentalis collected in California, Utah and Washington. The $r_{m}$ values reported here for G. occidentalis feeding on T. pacificus are somewhat lower than $r_{m}$ values reported for other phytoseiids feeding on the same prey species. For example, Takahashi and Chant (1994) reported $r_{m}$ values of $0.465,0.428$, 
0.386, and 0.326 for Phytoseiulus longipes Evans, $P$. persimilis Athias-Henriot, P. macropilis (Banks) and $P$. fragariae Denmark and Schicha, respectively feeding on all stages of $T$. pacificus at $26^{\circ} \mathrm{C}$. However, none of these predator mite species have been reported on grapes in California.

Our study shows that a detailed knowledge of the influence of temperature on $r_{m}$ for spider mites and their natural predators can provide useful information on conditions that could lead to the development of pest outbreaks. We showed that higher temperatures contribute to a higher $r_{m}$ for T. pacificus over the less damaging E. willamettei. Therefore, growers should monitor T. pacificus populations more carefully during hot periods, when the likelihood of outbreaks increases. Furthermore, management practices that elevate leaf temperature, such as deficit irrigation (Stavrinides et al. 2010b), should be implemented with caution as they can increase the risk for T. pacificus outbreaks. We also showed that higher temperatures may decrease the effectiveness of G. occidentalis against T. pacificus. For this reason, augmentative releases of $G$. occidentalis against T. pacificus should take place as early as possible, when temperature conditions are more favorable for the predator. If later releases are required, the predator-prey ratios would need to be adjusted to compensate for the increased performance of T. pacificus at higher temperatures. Additional studies on the effects of other factors such as grape variety, plant water stress, and relative humidity on life table parameters of the two spider mites and the predatory mite will further help us to develop a better understanding of spider mite outbreaks in vineyards and other cropping systems.

Acknowledgments This research was supported by scholarships to MC Stavrinides from the Robert and Peggy van den Bosch Memorial Scholarship in Biological Control and the Cyprus-America Scholarship program administered by the Fulbright Commission in Cyprus. Funding was also provided by the American Vineyard Foundation, the Viticulture Consortium West and the California Raisin Marketing Board. We thank A. Goldman, J. King, R. Lara and the undergraduate research apprentices who helped with laboratory observations. Steve Welter and Wayne Sousa read earlier versions of this manuscript and provided comments for its improvement. We also thank Duarte nurseries for supplying grape plants for this study.

Open Access This article is distributed under the terms of the Creative Commons Attribution Noncommercial License which permits any noncommercial use, distribution, and reproduction in any medium, provided the original author(s) and source are credited.

\section{References}

Badii MH, McMurtry JA (1984) Life history of and life table parameters for Phytoseiulus longipes with comparative studies on P. persimilis and Typhlodromus occidentalis. Acarologia 25:111-123

Benjamini Y, Hochberg Y (1995) Controlling the false discovery rate: a practical and powerful approach to multiple testing. J R Stat Soc B Met 57:289-300

Bentley WJ, Varela LG, Zalom FG, Smith RJ, Purcell AH, Phillips PA, Haviland DR, Daane KM, Battany MC (2006) UC IPM pest management guidelines: grape-insects and mites. University of California Agriculture and Natural Resources, Oakland, CA. http://www.ipm.ucdavis.edu/ PMG/selectnewpest.grapes.html. Cited Feb 102009

Bieri M, Baumgartner J, Bianchi G, Delucchi V, Von Arx R (1983) Development and fecundity of pea aphid (Acyrthosiphon pisum Harris) as affected by constant temperatures and by pea varieties. B Soc Entomol Suisse 56: 163-171

Birch LC (1948) The intrinsic rate of natural increase of an insect population. J Anim Ecol 17:15-26

Bolland HR, Gutierrez J, Flechtmann CHW (1998) World catalogue of the spider mite family (Acari: Tetranychidae). Koninklijke Brill NV, Leiden

Bonato O, Cotton D, Kreiter S, Gutierrez J (1990) Influence of temperature on the life history parameters of the yellow grapevine mite Eotetranychus carpini (Oudemans) (Acari: Tetranychidae). Int J Acarol 16:241-245

Bonfour M, Tanigoshi LK (2001) Effect of temperature on development and demographic parameters of Tetranychus urticae and Eotetranychus carpini borealis (Acari: Tetranychidae). Ann Entomol Soc Am 94:400-404

Bruce-Oliver SJ, Hoy MA (1990) Effect of prey stage on lifetable attributes of a genetically manipulated strain of Metaseiulus occidentalis (Acari: Phytoseiidae). Exp Appl Acarol 9:201-217

Carey JR (1993) Applied demography for biologists with special emphasis on insects. Oxford University Press, New York

Carey JR, Bradley JW (1982) Developmental rates, vital schedules, sex ratios, and life tables for Tetranychus urticae, T. turkestani and T. pacificus (Acarina: Tetranychidae) on cotton. Acarologia 23:333-345

Castagnoli M, Amato F, Monagheddu M (1989) Osservazioni biologiche e parametri demografici di Eotetranychus carpini (Oud.) (Acarina: Tetranychidae) e del suo predatore Typhlodromus exhilaratus Ragusa (Acarina: Phytoseiidae) in condizioni di laboratorio. Redia 72:545-557

Croft BA, McMurtry JA (1972) Comparative studies on four strains of Typhlodromus occidentalis Nesbitt (Acarina: Phytoseiidae). IV. Life history studies. Acarologia 13: $461-470$ 
Danks HV (2006) Short life cycles in insects and mites. Can Entomol 138:407-463

De Vasconcelos GJN, de Moraes GJ, Delalibera I, Knapp M (2008) Life history of the predatory mite Phytoseiulus fragariae on Tetranychus evansi and Tetranychus urticae (Acari: Phytoseiidae, Tetranychidae) at five temperatures. Exp Appl Acarol 44:27-36

English-Loeb G, Karban R, Walker MA (1998) Genotypic variation in constitutive and induced resistance in grapes against spider mite (Acari: Tetranychidae) herbivores. Environ Entomol 27:297-304

Escudero LA, Ferragut F (2005) Life-history of predatory mites Neoseiulus californicus and Phytoseiulus persimilis (Acari: Phytoseiidae) on four spider mite species as prey, with special reference to Tetranychus evansi (Acari: Tetranychidae). Biol Control 32:378-384

Flaherty DL, Huffaker CB (1970) Biological control of Pacific mites and Willamette mites in San Joaquin Valley vineyards. 1. Role of Metaseiulus occidentalis. Hilgardia 40: 267-308

Flaherty DL, Wilson LT, Welter SC, Lynn CD, Hanna R (1992) Spider mites. In: Flaherty DL, Christensen SP, Lanini WT, Marois JJ, Philips PA, Wilson LT (eds) Grape pest management. University of California, Division of Agriculture and Natural Resources, Oakland, California, pp 180-192

Frazier MR, Huey RB, Berrigan D (2006) Thermodynamics constrains the evolution of insect population growth rates: "Warmer Is Better". Am Nat 168:512-520

Giraudoux P (2008) pgirmess: data analysis in ecology. R package version 1.3.7. http://pagesperso-orange.fr/girau doux. Cited 15 Mar 2009

Gotoh T, Yamaguchi K, Mori K (2004) Effect of temperature on life history of the predatory mite Amblyseius (Neoseiulus) californicus (Acari: Phytoseiidae). Exp Appl Acarol 32: $15-30$

Grissa-Lebdi GL, Van Impe G, Lebrun P (2002) Demographic traits of Eotetranychus pruni from Belgian and Tunisian orchards in comparison with Tetranychus urticae. Exp Appl Acarol 26:209-217

Hanna R, Wilson LT (1991) Prey preference by Metaseiulus occidentalis (Acari: Phytoseiidae) and the role of prey aggregation. Biol Control 1:51-58

Hougen-Eitzman D, Karban R (1995) Mechanisms of interspecific competition that result in successful control of Pacific mites following inoculations of Willamette mites on grapevines. Oecologia 103:157-161

Hoy MA, Smilanick JM (1981) Non-random prey location by the phytoseiid predator Metaseiulus occidentalis: differential responses to several spider mite species. Entomol Exp Appl 29:241-253

Janssen A, Sabelis MW (1992) Phytoseiid life histories, local predator-prey dynamics, and strategies for control of tetranychid mites. Exp Appl Acarol 14:233-250

Karban R, English-Loeb G, Hougen-Eitzman D (1997) Mite vaccinations for sustainable management of spider mites in vineyards. Ecol Appl 7:183-193
Kasap I (2004) Effect of apple cultivar and of temperature on the biology and life table parameters of the twospotted spider mite Tetranychus urticae. Phytoparasitica 32:73-82

Maia AHN, Luiz JBA, Campanhola C (2000) Statistical inference on associated fertility life table parameters using jackknife technique: computational aspects. J Econ Entomol 93:511-518

Nomikou M, Janssen A, Schraag R, Sabelis MW (2001) Phytoseiid predators as potential biological control agents for Bemisia tabaci. Exp Appl Acarol 25:271-291

R core development team (2008) R: A language and environment for statistical computing. R Foundation for Statistical Computing, Vienna, Austria. ISBN 3-900051-07-0. http://www.R-project.org. Cited Mar 152009

Roy M, Brodeur J, Cloutier C (2003a) Effect of temperature on intrinsic rates of natural increase $\left(\mathrm{r}_{\mathrm{m}}\right)$ of a coccinellid and its spider mite prey. BioControl 48:57-72

Roy M, Brodeur J, Cloutier C (2003b) Temperature and sex allocation in a spider mite. Oecologia 135:322-326

Sabelis MW (1985) Reproductive strategies. In: Helle W, Sabelis MW (eds) Spider mites: their biology, natural enemies and control. volume 1A. Elsevier Science Publishers BV, Amsterdam, pp 265-278

SAS Institute Inc. (2004) SAS/STAT® 9.1 user's guide. SAS Institute Inc, Cary, NC

Stavrinides MC, Mills NJ (2009) Demographic effects of pesticides on biological control of Pacific spider mite (Tetranychus pacificus) by the western predatory mite (Galendromus occidentalis). Biol Control 48:267-273

Stavrinides MC, Lara JR, Mills NJ (2010a) Comparative influence of temperature on development and biological control of two common vineyard pests (Acari: Tetranychidae). Biol Control 55:126-131

Stavrinides MC, Daane KM, Lampinen BD, Mills NJ (2010b) Plant water stress, leaf temperature, and spider mite (Acari: Tetranychidae) outbreaks in California vineyards. Environ Entomol 39:1232-1241

Takafuji A, Chant DA (1976) Comparative studies of two species of predacious phytoseiid mites (Acarina: Phytoseiidae), with special reference to their responses to the density of their prey. Res Popul Ecol 17:255-310

Takahashi F, Chant DA (1994) Adaptive strategies in the genus Phytoseiulus Evans (Acari: Phytoseiidae). II: survivorship and reproduction. Int J Acarol 20:87-97

Tanigoshi LK, Hoyt SC, Browne RW, Logan JA (1975) Influence of temperature on population increase of Metaseiulus occidentalis (Acarina: Phytoseiidae). Ann Entomol Soc Am 68:979-986

Welter SC, Farnham DS, McNally PS, Freeman R (1989) Effect of Willamette mite and Pacific spider mite (Acari: Tetranychidae) on grape photosynthesis and stomatal conductance. Environ Entomol 18:953-957

Youngman RR, Sanderson JP, Barnes MM (1988) Life history parameters of Tetranychus pacificus McGregor (Acari: Tetranychidae) on almonds under differential water stress. Environ Entomol 17:488-495 